A publication of the Muma College of Business | University of South Florida

\begin{abstract}
Volume 4
Number 16

31 DECEMBER 2019

MARIA KHILKOVSKAIA, SNEHIL TIWARI, ALEXANDRE SEITI MIGUEL, CHAD COWAN, MICHAEL EISENBERG
\end{abstract}

\title{
A DEDICATION THAT DRIVES THE GROWTH ${ }^{1}$
}

As the sun went down on a Friday evening and everyone in the office started rushing home, Michael Eisenberg, logistics manager at World Direct Shipping, LLC (WDS), found himself glued to his desktop. He kept his glasses down on the table and stared at the whiteboard in the boardroom. He envisioned how one wrong data entry could jeopardize the entire system resulting in the hold of cargo by Customs and Border Protection (CBP). One of the containers that arrived in the morning was full of plantains, but because of the inaccurate data entry, the documentation for CBP listed bananas and not plantains. Since the commodity was entered incorrectly, CBP placed the entire shipment on hold until further notice. The customers were waiting, and the plantains were rotting.

Eisenberg was exhausted from advising the customers and simultaneously trying to convince his seniors that the logistics systems needed to be improved. His company was experiencing growth, and he was not able to fulfil the demand. Currently, the company used Salesforce, Descartes AMS and Microsoft Excel. All the entries made were manual and required employees to copy and paste information occupying multiple extra hours per week to satisfy all the requirements. The major problem was the data tracking system as the input to the system was from different sources. Michael felt the need of implementing a software solution to enhance decision making as the current system was becoming a headache for him.

By implementing a better solution for shipment tracking, Michael wanted to facilitate better overall delivery service between WDS and its customers. The hardest question was that he did not know where to start. The quick solution of implementing an Electronic Data Interchange (EDI) system would solve most problems related to copying and pasting data. However, it might not help in the long run because the company was expanding. To address market trends and prosper in the next few years, WDS needed to make significant updates to its logistics systems including RFID implementation and create a better solution for Enterprise Resource Planning (ERP).

All of these thoughts were racing through Michael's head as he considered the best approach for WDS moving forward. Would transitioning to EDI be enough to make them competitive for the future? Would imports decrease as a result of implementing EDI? Would the company's current software programs be able to support EDI? Would utilizing RFID lead to a better customer experience? How expensive would it be to implement RFID for WDS? Michael thought to himself that these were not going to be easy decisions to make.

\footnotetext{
${ }^{1}$ Copyright (C) 2019, M. Khilkovskaia, S. Tiwari, A.Miguel, C. Cowan, M. Eisenberg. This case was prepared for the purpose of class discussion, and not to illustrate the effective or ineffective handling of an administrative situation. This case is published under a Creative Commons BY-NC license. Permission is granted to copy and distribute this case for non-commercial purposes, in both printed and electronic formats
} 


\section{Industry Background}

WDS belonged to the Supply Chain Management industry, particularly logistics. Logistics was the process of moving "products or services to a designated location at an agreed upon time, cost and condition" (Hopkins Distribution Company, 2013). However, there were a lot of other important considerations that made the logistics industry successful. Many facets needed to be considered for a logistics company to operate effectively:

1. The form of transportation could impact the arrival time of deliveries.

2. The temperature while being transported could impact the life of a product.

3. The systems used for tracking the storage and transportation of goods were crucial for transparent operations.

\section{Origins}

\section{History of Logistics}

The history of logistics had changed technologically, but its importance remained the same. The term for logistics was first used by the Roman military, beginning in 264 B.C. (Roth, 1999). The various roles and responsibilities that the Roman officers had were what led to them using this term. They were responsible for the training of troops, supplying weapons in war, and strategizing the most effective military tactics to use in battle. What once began as military terminology had transitioned into a fundamental process that was used across most businesses at the time of the case.

The development of logistics from the military to civilization happened around the 5 th century during the middle ages. Right before that time was when the Roman empire fell. The Romans built efficient transportation routes for their military which were comprised mainly of roadways and canals. European civilians during the middle ages began to repair these routes to use them for the transportation of goods.

Due to the development of transportation, the middle ages began to capitalize on the logistical methods that the Romans used. Before the development in transportation, towns would depend on their communities to meet all of their material needs. However, with expansion in routes between towns, they had a more natural way to communicate and transport goods. They would store the goods within forts or warehouses to make sure they were protected. Manufacturing during this era often occurred in people's homes and was done by using hand tools ("Industrial Revolution," 2009). Production of goods was normally handled on demand since manufacturing was a time-consuming task. The logistics process was vital to the growth and enhancement of civilization.

As technology continued to develop, so did the logistics industry. The industrial revolution from the 18th century to the 19th century brought about an unprecedented change in logistics. Manufacturing and transportation of goods began to utilize automated machines, saving time and energy for the workers. The advancement of the railroad system with the development of steam engines and water shipment were vital components that emerged during the industrial revolution. For the first time, products were being transported at a rate that had never been done before. Another area that aided the logistics industry during the 18th century was the advancements in communication. The invention of the telegraph allowed companies to foster clear communication between each other. Communication was vital in the logistics industry to make sure that deliveries were made as specified. 


\section{Logistics for the Food Industry}

The logistics aspects in the food industry had some unique qualities compared to logistics in other sectors. The transportation of food became most prominent during the industrial revolution. The topics listed below were essential factors for companies to consider when transporting food:

1. Avoid Spoilage: Food did not have the same shelf life as other products. For example, fruits and vegetables began to spoil the moment that they were harvested. If fruits and vegetables were not delivered on time, the food could become inedible and harmful to consumers.

2. Preservation: There were various steps needed to make sure that food was preserved. Some items needed to be stored in climate-controlled containers. If food was not stored correctly, it could lead to "contamination which is a serious health hazard that can even lead to the death of the consumer. Ensuring high standards of hygiene and cleanliness is one of the chief transportation and logistics considerations of the food industry" ("A Brief History," 2014). Failure to properly store food could cause drastic effects on a business.

3. Risk of Damage: Food could be easily damaged since it was very fragile. One of the core reasons food was damaged was because of improper packaging. Some companies would try to change the packaging as a cost-cutting measure, but often it lead to weaker packing material which could damage the product during shipments (Ackerley et al., 2010).

\section{Company Overview}

\section{World Direct Shipping, LLC (WDS) Background Information}

WDS was a shipping line that began operations on November 4th, 2014. It was a subsidiary company of Your Dekalb Farmers Market, Inc. (YDFM). YDFM is a farmer's market located in Decatur, GA that specialized in food, mainly imported fruits and vegetables. Most of their foods were imported year-round. The most popular imports included plantains, bananas, papayas, malanga coco, limes, mangoes, and pineapples. The owners of YDFM, Robert Blazer and Daniel Blazer became distraught from using thirdparty logistics services and realized that an in-house shipping line would allow them to create shorter lead times from the growers in Mexico to their farmer's markets.

In the beginning, the company had two small offices, one in Palmetto, FL and another one in Coatzacoalcos, MX. The Palmetto office had a total of three employees (two commercial directors and one operations manager); the Coatzacoalcos office had six employees (two customer service representatives, two logistics managers, and two container yard workers). During the first year of operations, WDS imported cargo only for YDFM, and they used Port Manatee as a distribution center. As WDS grew, the customer base expanded as well. The commercial directors started finding new business opportunities, and other customers began using WDS services weekly.

\section{Operations and Business Model}

The operations began in two ports: Port Manatee, FL, and Port Coatzacoalcos, MX, with a two-and-ahalf-day vessel transit time. WDS leased all their containers and used 40' HC reefer containers and 40' $\mathrm{HC}$ dry containers in their fleet (see Exhibit 1). WDS chartered the first vessel, $\mathrm{m} / \mathrm{v}$ Falmouth, that sailed between Port Manatee and Port Coatzacoalcos on a weekly basis. The operations managers were tracking the freight that arrived weekly so that CBP was aware of all the imports; whereas the logistics managers 
were scheduling the deliveries of all the new customer's cargo. All trucks scheduled by WDS were contracted out. WDS did not have any in-house carriers.

On July 26, 2016, WDS purchased its first vessel and named it m/v Queen B (see Exhibit 2). The vessel was named after Robert's wife, Barbara Blazer. Queen B is 132 meters (433 feet) long and can stow up to 250 full containers. WDS had two cargo vessels in its service, the chartered Falmouth and the owned Queen B. One vessel called on Port Manatee each week, so each vessel was arriving bi-weekly. To keep the service on schedule, sometimes the vessels would drop anchor in Mexico and wait to sail back to Port Manatee. WDS wanted to keep its vessels arriving every week on Tuesdays, so it would not fall behind its competition.

In 2019, WDS began calling on five ports in total: Port Manatee, FL; Port Pensacola, FL; Port Tampico, MX; Port Tuxpan, MX; and Port Coatzacoalcos, MX. Not only did WDS begin calling on five ports, but they also on-hired a third vessel. At this time, WDS owned one vessel $\mathrm{m} / \mathrm{v}$ Queen B and chartered two vessels: $\mathrm{m} / \mathrm{v}$ Lena and m/v Runa. The Queen B and Runa followed the standard loop service, calling on Port Manatee, Port Pensacola, Port Tampico, Port Tuxpan and Port Coatzacoalcos. The Lena was an express service vessel and was calling on Port Manatee, Port Tuxpan, and Port Tampico, but only for 20' ISO tanks and 20' flexitanks. The operations of loop services and express services were demonstrated in Exhibit 3. Even though YDFM used WDS services all year round, most other customers were seasonal. The busy season usually took place from January to May. After May, WDS would go back to using two vessels, and the express service vessel would off-hire until next January. By August 2019, WDS planned to own their second vessel.

WDS was also referred to as a vessel operating a common carrier, or VOCC. The first supply chain interactions begin in Mexico, and then the process was shifted to the United States once the vessels departed from Mexico. Customers created bookings (one booking was equivalent to one Bill of Lading) and sent the reservations to WDS customer service employees in one of three ports in Mexico: Port Tampico, Port Tuxpan, and/or Port Coatzacoalcos. Refer to Exhibit 4 for sample standard Bill of Lading. The customer service employees entered the booking information into Salesforce, and then the logistics department in Mexico scheduled the pickup of the freight if it was a door-to-door move, or allowed the customer to pick up the containers and bring them back full if it was a CY (container-yard) move. The bookings were compiled up to a maximum of two days before the vessel returned, and the cut-off was 24 hours before the vessel's arrival to avoid delaying the vessel from its departure. Once the containers were inside the container yard waiting to be loaded on the vessel, the commercial team in the United States compiled all of the data from Salesforce and entered it manually into the Descartes AMS system.

The WDS business model was quite simple. The company mainly made money by charging customers who used their shipping line services. Containers were booked and WDS charged their customers based on each container loaded on each vessel. WDS also made money by delivering some containers. WDS did not deliver all containers that had sailed on their vessels, but they did offer delivery services that allowed them to make additional profits. WDS competencies included providing the best service to all customers, as well as creating shorter lead times to significant customers. WDS provided fewer steps in the supply chain so that customers could receive their freight faster.

\section{Company Philosophy}

Robert Blazer, the owner of YDFM and WDS, had a philosophy that two different personalities attract. Following this idea, all the employees were required to work in pairs. One employee was considered to have an expanding personality, while the other employee was deemed to have the contracting personality. Robert interviewed all his employees and decided which personality they had during the interview. The employees with the expanding personality were deemed as the "free thinkers." These were the employees 
that went above and beyond and were constantly thinking of ways to improve their daily tasks while coming up with solutions to things that were not working out. The employees with the contracting personalities were deemed as the employees that followed a strict "daily routine." If there was a change in the routine, it could throw off these employees. Robert believed that expanding and contracting personalities were the yin and yang in the workplace.

What began as a small one vessel operation, had evolved into a massive three vessel operation in only five years. In 2019, WDS had employees at Port Manatee, Port Tampico, Port Tuxpan, and Port Coatzacoalcos. WDS did not have any employees at Port Pensacola; the operators in Pensacola were contracted to handle all of the freight. At the central office (Port Manatee), there were nine employees: one commercial director, two vessel agents, one logistics manager, one vessel operations coordinator, two customer service/commercial representatives, and two accountants. Although the owners of WDS hired their employees to work in pairs, sometimes it took them a while to fill the open positions. Eventually, the owners hired a second commercial director, a second logistics manager, and a second vessel operations coordinator.

\section{Market and Competition}

\section{Direct Competitors}

WDS only had one direct competitor: TransGulf. TransGulf service called on Port Tampa, FL, and Port Tuxpan, MX. They offered a very similar service to what WDS offered, such as the same two-and-a-halfday transit time, door-to-door shipping service, 40' HC reefers, etc. The major difference between the two companies was that TransGulf called on port Tuxpan, while WDS called on port Coatzacoalcos. Solely because of the existence of a direct competitor, WDS began to grow. After facing the direct competitor in the early years of WDS operations, Robert and Daniel spoke to their customers and determined that there was a big opportunity for them if they also called on Tuxpan. Not only would this increase business, but with two vessels, WDS could begin giving TransGulf's customers a second transit option. Because the right decisions were made at the right time, TransGulf customers began finding out about WDS, and some of them even switched over to use WDS services. WDS also decided to expand in the US and began calling on Pensacola, FL to help deliver freight to customers in the Midwestern United States. YDFM still used Port Manatee instead of Pensacola because Port Manatee had a more extensive operation, there was more warehouse space in Port Manatee, and there were also more trucking opportunities in Port Manatee.

\section{Indirect Competitors}

The Logistics and shipping industry was diverse and vast. Some of the most significant international container shipping companies like A.P. Moller-Maersk Group and Hapag-Lloyd might not cause a direct threat to a small company like WDS, but industry giants always came up with new trends that later needed to be adopted by smaller companies. It was crucial to keep in mind that big companies usually set standards of operations for all smaller companies. Also, aside from container shipping companies, international courier delivery services like FedEx and UPS set up trends for logistics as well. Even though all these big names would probably never cross paths with WDS, it was crucial to keep track of upcoming industry trends and adopt them sooner rather than later to stay competitive. 


\section{Technology in the Logistics Industry}

\section{WDS Current Logistics Systems}

WDS used two significant systems: Salesforce for shipment information management and Descartes AMS to submit the required shipment information to CBP. WDS also used Microsoft Excel daily to store data and to exchange data between systems. Employees used these systems to input shipment schedules, shipment lines, and shipment items, to create a bill of lading, booking information, CBP shipment information submission, and other processes along the shipment cycle.

\section{Salesforce}

Salesforce's Streamline application profiled full shipment life-cycle management. This software provided the following features: Account \& Contact Management, Purchase Order Management, Quote Management, Shipment Management, Container Management, Item Management, Invoice Management, and Payment Tracking. Salesforce Streamline was ready to use out of the box; however, WDS worked with the Salesforce developers' team to tailor the platform to their business needs.

- Account \& Contact Management: allowed companies to efficiently manage and maintain accounts including prospects, vendors, clients, and competitors. The Accounts module served as the backbone of Streamline Shipping as all transactions were related to it. The system maintained pertinent information for each account such as contacts, billing, shipping addresses, and other necessary details.

- Quote and Purchase Order Management: Quote Management provided accurate, detailed quotes to WDS clients. With the Price book feature, shipment information such as destinations, containers, and items could be automatically entered for repeat clients, saving time and reducing human error. In order management, users could specify a delivery date, item identification, quantities, shipping terms, payment terms, and all other obligations and conditions. Purchase orders were easily converted to shipments, cutting down duplicate work and preventing errors.

- Shipment and Container Management: Container Management came with standard industry containers, preloaded dimensions and weights included (see Exhibit 5). This came in very handy when shipping fragile items or hazardous material since the characteristics of a shipment could be attached to the documentation. WDS specified ship dates, arrival time, shipping instructions, and any necessary documents (see Exhibit 5.1).

\section{Descartes AMS}

The Descartes Automated Manifest System (Descartes AMS) software provided solutions for shipping companies to manage shipment information electronically and enabled compliance with the requirement to electronically submit shipment information to the U.S. Customs Department's Automated Manifest System for ocean cargo (see Exhibit 6). The Descartes AMS helped to manage an ever-increasing amount of legally required containerized shipment information in a small window of time. Exhibit 6.1 and 6.2 show Descartes AMS interface for Application Status, Deposition Status, Voyage Status, Ports of Load, and Discharge.

The most essential features of Descartes AMS and the features used by WDS were the electronic information submission to customs authorities and the status query (see Exhibit 6.3 and 6.4). The system transmited electronic information to customs authorities in their required proprietary data format, ensuring compliance with U.S. Customs' CSI programs. Users ccould electronically submit queries in a Web form to determine the status of an individual cargo manifest. Descartes AMS also enabled searches 
using the same necessary information included in the actual paper document, that included bill of lading, container number, and port of origin. WDS employees could print a list of status information, such as: "released," "on hold," etc.

\section{Problems with Current Systems}

WDS did not have technologically advanced logistics systems. Each of the operations described were used separately, and the data-flows between them were made manually by WDS employees using Microsoft Excel. This process occurred multiple times from one system to another. Information was extracted from all systems before inputting data to the continuous flow of operations. The customer service process began in Salesforce where the employees entered the booking information and schedules. Once the containers were inside the container yard waiting to be loaded on the vessel, the US commercial team ran a report with all of the Salesforce data, converted the report to Microsoft Excel, and then manually entered the manifest information into the AMS system. The AMS system required all the information presented on the bill of lading, so the commercial team copied the data from Microsoft Excel into AMS for every bill of lading on the voyage and then submitted the data to CBP.

The vessel operations coordinator took the container information from Salesforce and ran a report based on the vessel's status from each port. She then copied all the data from Salesforce, pasted it into Microsoft Excel and used a pivot table that was programmed to determine how many containers were located in each port and how many containers were currently shipped in-transit. The logistics manager created a custom report within Salesforce that keyed to all the door-to-door moves in the US and ran this report for every vessel that arrived each week. The report was also exported to Microsoft Excel and then once all deliveries were completed for the week, the deliveries were put into a master Excel spreadsheet containing all of the deliveries made by WDS for tracking and billing purposes. The commercial director worked with the customer service representatives in Mexico to determine how many bookings were received each week and could forecast how many empty containers were needed for each port based on the booking information and pivot table information.

\section{Trends in Logistics Systems}

Technology strategy and implementation were one of the 8 logistics challenges faced by the industry (see Exhibit 7). The industry had an imminent need for a business intelligence solution integrated with ERP and running on cutting edge technology. The shipping industry was benefiting from the advancement in technology, and for the next few years understanding these logistics technology trends would be crucial to success or failure. The customers and regulatory agencies were demanding more. Technology was the solution for service providers for achieving more effective and efficient operations.

\section{Transportation Management Systems (TMS)}

The use and adoption of Transportation Management Systems (TMS) were expected to climb within the shipping industry. "Over the next five years the Shipping Software market would register an 8.3\% CAGR in terms of revenue, the global market size would reach US\$ 1880 million by 2024, from US\$ 1160 million in 2019," said a Reuters analyst ("Shipping Software market," 2019). TMS was valuable for all logistics interactions and processes, including route planning and optimization, freight auditing and payment processing, carrier management, etc. As a result, more companies would adopt such solutions to keep up with increased demand and integrate the increased use of logistics technology. Shipping software permitted shipping companies to prepare documents from a single system, which allowed managing quotes, orders, shipping, compliance, and regulatory tasks easily. It also permitted shipping companies to 
KHILKOVSKAIA, TIWARI, MIGUEL, COWAN, EISENBERG

secure the transit times, and arrival dates for each shipment individually. An average cost of a TMS system development and implementation was up to \$200,000 (Vysochynska, 2018), however many variables needed to be considered to define the values of a company's operation.

\section{Blockchain}

Block chain technology enabled users to keep a list or a record of transactions, in chronological order. This technology was created as a support system to organize digital currency and its transactions. The block chain technology allowed digital information to be distributed but not copied, by several users on a platform. This form of the virtual ledger recorded everything that had value if it was programmed to do so. This technology had potential to be used in the shipping industry. Block chain could be used to improve global trade and digitize the supply chain by keeping a transparent ledger where multiple companies could see the records of transactions and thus work towards improving them. Block chain technology was expected to replace the older system of the shipping industry of bills and transactional documents. This would secure an online mechanism for the trade of goods. Since technology was decentralized, it also made it more efficient and completely transparent.

\section{Electronic Data Interchange (EDI)}

Electronic Data Interchange (EDI) was the computer-to-computer exchange of business documents in a standard electronic format between separate systems within the organization or with business partners. EDI replaced postal mail, fax, email, and copy and paste from systems. Having people involved slows down the processing of the documents and data. EDI documents could flow straight through to the appropriate application to the next system and allowed the following process to begin immediately (see Exhibit 8). There were several EDI standards in use, they included: ANSI, EDIFACT, TRADACOMS, and ebXML. When two different systems needed to exchange EDI documents, they must be aligned on the specific EDI standard and version. Businesses typically used an EDI translator--either as in-house software or via an EDI service provider--to translate the EDI format so the data could be used by their internal applications and thus enabled straight-through processing of documents. An EDI system cost depended on the type of contract, or if the company decided to purchase the system. However, the average cost to companies on EDI was $\$ 1$ to $\$ 3$ per transaction or an annual fee of $\$ 25,000$ (Babati, 2019).

\section{Radio Frequency Identification (RFID)}

RFID, which stood for Radio Frequency Identification, used radio waves to identify objects, freight, containers, and many other objects. There was a device that read the information contained in a wireless device or "tag" (see Exhibit 9), from a distance without making any physical contact or requiring a line of sight. In the world of packaging and shipping, RFID offered more than just protection against theft and fraud. It helped businesses track damage, loss, error, expiration, slow delivery, etc. RFID allowed companies to track containers in each part of the supply chain. Active RFID Tags could be used to track containers in real-time at yards and docks. Ultra-high frequency RFID had long identification distance and speeds up identification. The significant improvements RFID could make to shipping businesses were visibility of real-time cargo movement, accelerated speed of delivery, accuracy, and efficiency. With RFID, shipping companies had an opportunity to be at the cutting edge of a phenomenon that was changing the world. The cost of RFID sensors had decreased exponentially in recent years, and shipping providers could take advantage of these technologies without necessarily increasing the rate of shipping. The prices of the RFID readers were around $\$ 1,000$ up to $\$ 3,000$. Tags could cost from $\$ 5$ to $\$ 15$ (Ray, 2018). Also, additional cables, network upgrades, installation and maintenance for the RFID system must be considered. 


\section{Summary}

Michael was concerned with the company's future. The logistics manager position at WDS was Michael's first long-term employment, and he was able to see first-hand how the company grew in the last few years. The potential for future operations was great, and Michael wanted to be a part of it. He desired to make WDS operations better because he wanted to stay with this company for the long-term.

The most frustrating duty that WDS performed daily was copying and pasting various data from one system to another; thus, the problem could be easily solved with an EDI system. Nothing else caused more issues than this "copy-paste" routine. Besides, the implementation of RFID chips was inevitable. Michael realized that WDS was still a small company, and the RFID chips were expensive. Upper management might not currently agree to invest in these chips; but, it was vital for them to consider RFID chip implementation for the future. To make RFID implementation smooth and quick, it was essential to adjust all current systems to be compatible with this new technology.

If WDS would start updating the current systems and implementing EDI and RFID, there was a greater chance that many things would go wrong with Salesforce and current data storage in Microsoft Excel. You could not start using new advanced technology and expect that old systems would be just fine as they were. There were better solutions for ERP and shipment management systems than Salesforce that were already compatible with new technologies such as RFID. Also, cloud-based data storage was more promising than Microsoft Excel sheets with hundreds of thousands of recorded data. Hapag-Lloyd, the industry giant, had a fleet of 219 vessels and a company of this size should have all the latest technologies in order to provide the best services. WDS was expanding, but their current goal was to own two vessels and charter one if needed. WDS did not need to have all of these modern technologies because of its size. The company was profitable, and operations were on a higher-quality level.

\section{The Decision}

After researching current trends in the logistics systems and identifying major issues in WDS, Michael Eisenberg came up with four possible solutions:

\section{Option 1: "Quick Fix"}

WDS could adopt an EDI system that would take all of the data from Salesforce and paste it into the fields in Descartes AMS in a few seconds.

\section{Pros:}

- The computer would do all the work and ultimately alleviate the 10 hours spent weekly on this technical process.

- Cost-effective solution that would not take much time to implement and would solve the major problem.

\section{Cons:}

- Additional changes might be required to make EDI, Salesforce and AMS systems interconnected.

- The process of updating all the systems to make them compatible with EDI would take an increased effort even though this option was the quickest and the most cost-efficient. 


\section{Option 2: "RFID + EDI"}

WDS was expanding and investing in RFID was required for better tracking capabilities of all containers. There was no point in making updates solely for implementing EDI since in the next few years WDS would undergo the same process of updating systems to make them connected with RFID. To make sure that the process would not be repeated twice and to avoid extra expenses, it would be smart to start with the implementation of both RFID and EDI simultaneously.

\section{Pros}

- Addressing current trends was one of the keys to success.

- RFID implementation would make the operations of WDS more transparent; thus, customers would consider the company more reliable.

\section{Cons}

- WDS was a small company, and the RFID chips were costly, primarily if they would be implemented on all containers.

- Even though it was important to look ahead of time, upper management might not agree to invest in the RFID chips at the time of the case.

\section{Option 3: "All In"}

If WDS upper management would agree to start the implementation of logistics systems, then it was worth it to completely renew the whole infrastructure of data storage and data management. A better ERP solution along with cloud-based data storage would perfectly compliment the RFID chips and new tracking system.

\section{Pros}

- Modernization of the systems would help the company to grow.

- With new technologies implemented, WDS could operate safely for many years to come without worrying about trends or being non-compliant with regulatory policies.

\section{Cons}

- Required much effort, time and money to implement.

- Would cause significant disruptions to current operations since all the systems would need to be updated.

- Potentially could cause data damage or data loss during the implementation process.

\section{Option 4: "Do Nothing"}

WDS was a small family-owned company. Upper management was not planning to create a large modern logistics and shipping corporation. All companies face some issues, but WDS's older technology never caused major problems, only short-term delays. Sometimes small businesses did not need to incorporate new technology in order to operate effectively and efficiently. 


\section{Pros}

- Without any renovations, WDS would continue to operate effectively and without any disruptions.

- With current logistics systems, there was no need for additional budget spending.

\section{Cons}

- Potentially, the company might lose its competitive advantage to both direct and indirect competition.

- If new governmental regulations were introduced, a small company like WDS would not be able to react quickly and make necessary updates which could cause major damage to the operations and the reputation of the company.

Many issues influenced Eisenberg on whether or not to proceed with his decision. He wanted to improve his work environment and help his company reach new goals. Dedication was always honorable, but it was frustrating to pursue large goals without additional support. Option one was selected, and Michael scheduled a meeting with upper management during the next week at the time of the case. He still had a few days to analyze all of his options and was passionate about the idea that he might achieve these goals. 


\section{KHILKOVSKAIA, TIWARI, MIGUEL, COWAN, EISENBERG}

\section{References}

Ackerley, N., Sertkaya, A., \& Lange, R. (2010, April). Food transportation safety: Characterizing risks and controls by use of expert opinion. http://www.foodprotection.org/files/food-protectiontrends/Apr-10-Ackerley.pdf

Babati, B. (2019, February 22). EDI pricing. https://www.youredi.com/blog/edi-pricing

Food Logistics. (2014, July 14). A brief history of the food supply chain - Food (and more) for thought July 2014. https://www.foodlogistics.com/safety/article/11538965/a-brief-history-of-the-foodsupply-chain-food-and-more-for-thought-july-2014

History.com Editors. (2009, October 29). Industrial revolution. https://www.history.com/topics/industrial-revolution/industrial-revolution

Hopkins Distribution Company. (2013, July 26). History of logistics, distribution and supply chain management. https://www.hdcusa.com/news/history-of-logistics-distribution-and-supply-chainmanagement/

Ray, B. (2018, February 13). A breakdown of 7 RFID costs, from hardware to implementation. https://www.airfinder.com/blog/rfid-cost

Reports and Markets. (2019, February 21). Shipping Software market will register a 8.3\% CAGR in terms of revenue, the global market size will reach US\$1880 million by 2024. https://www.openpr.com/news/1605025/shipping-software-market-will-register-a-8-3-cagr-interms-of-revenue-the-global-market-size-will-reach-us-1880-million-by-2024.html

Roth, J. P. (1999). The logistics of the Roman army at war (264 B.C.-A.D. 234). Leiden: E.J. Brill. http://www.legioxxirapax.com/zasoby/The Logistics_of the Roman_Army_at_War_(264BC_235AD).pdf

Vysochynska, O. (2018, June 13). How much does it cost to build a transportation management system? https://stfalcon.com/en/blog/post/TMS-development-cost 


\section{Biographies}

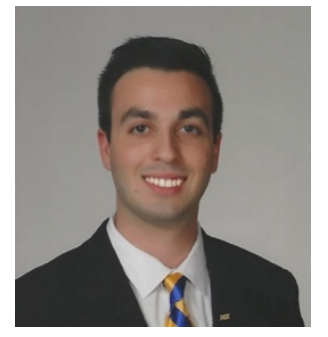

Michael Eisenberg, the protagonist, holds a Master of Science degree in Marketing with a specialization in Supply Chain Management from the University of South Florida. He has over 3 years of experience working in Supply Chain Management, working as a Logistics Manager for World Direct Shipping, LLC. Prior to this role, he was an Operations Manager at World Direct Shipping, LLC, where he entered data weekly in the company's systems, as well as, entered manifest data for Customs and Border Protection.

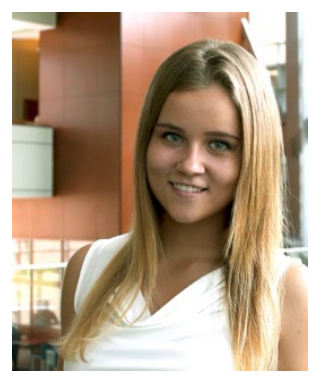

Mariia Khilkovskaia is an international student from Moscow, Russia. She graduated from the University of South Florida with a Bachelor of Arts degree in Mass Communications. Currently, she is a member of the University of South Florida Muma College of Business's 2020 MBA cohort. She is also pursuing Master of Science degree in Marketing and specializes in supply chain management and data analytics.

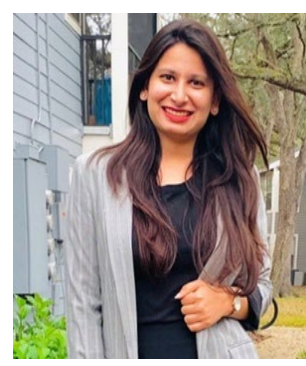

Snehil Tiwari is an international student from India with an undergraduate degree in Bachelor of Dental Surgery and currently pursuing a Master's degree in Business Administration with Healthcare specialization at the University of South Florida. Prior to USF, Snehil has worked in different facets of healthcare as an Assistant Manager in one of the renowned hospitals in India. This is where her interest in the business aspect of healthcare began. She is a result-oriented professional with two years of work experience in strategy \& operations in the healthcare industry.

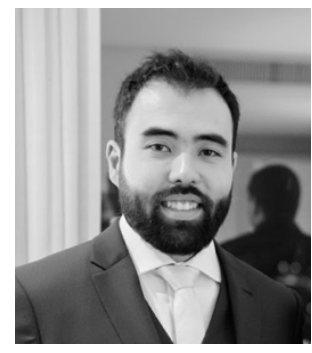

Alexandre Miguel is a full-time graduate student at the University of South Florida pursuing a Master's degree in Business Administration. He is an international student from Brazil graduated with a Bachelor of Mechanical Engineering. Alexandre had worked several years in risk management for financial institutions. He spent the last four years working in the consulting and management business focused in healthcare. 


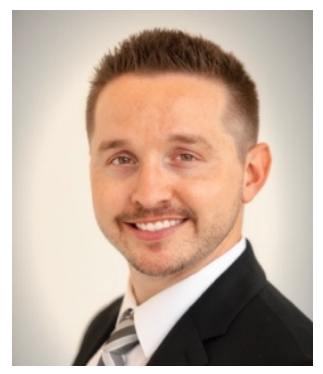

Chad Cowan is a student in the University of South Florida Master of Business Administration program with a concentration in management. In addition, Chad hold a Bachelor of Science in Marketing from the University of South Florida. He has worked the past three years as an Insurance Agent at USAA. Prior to that, he worked at Tech Data as a Business Development Representative in the IT distribution industry. 


\section{Exhibit 1: 40' Dry High Cube Containers}

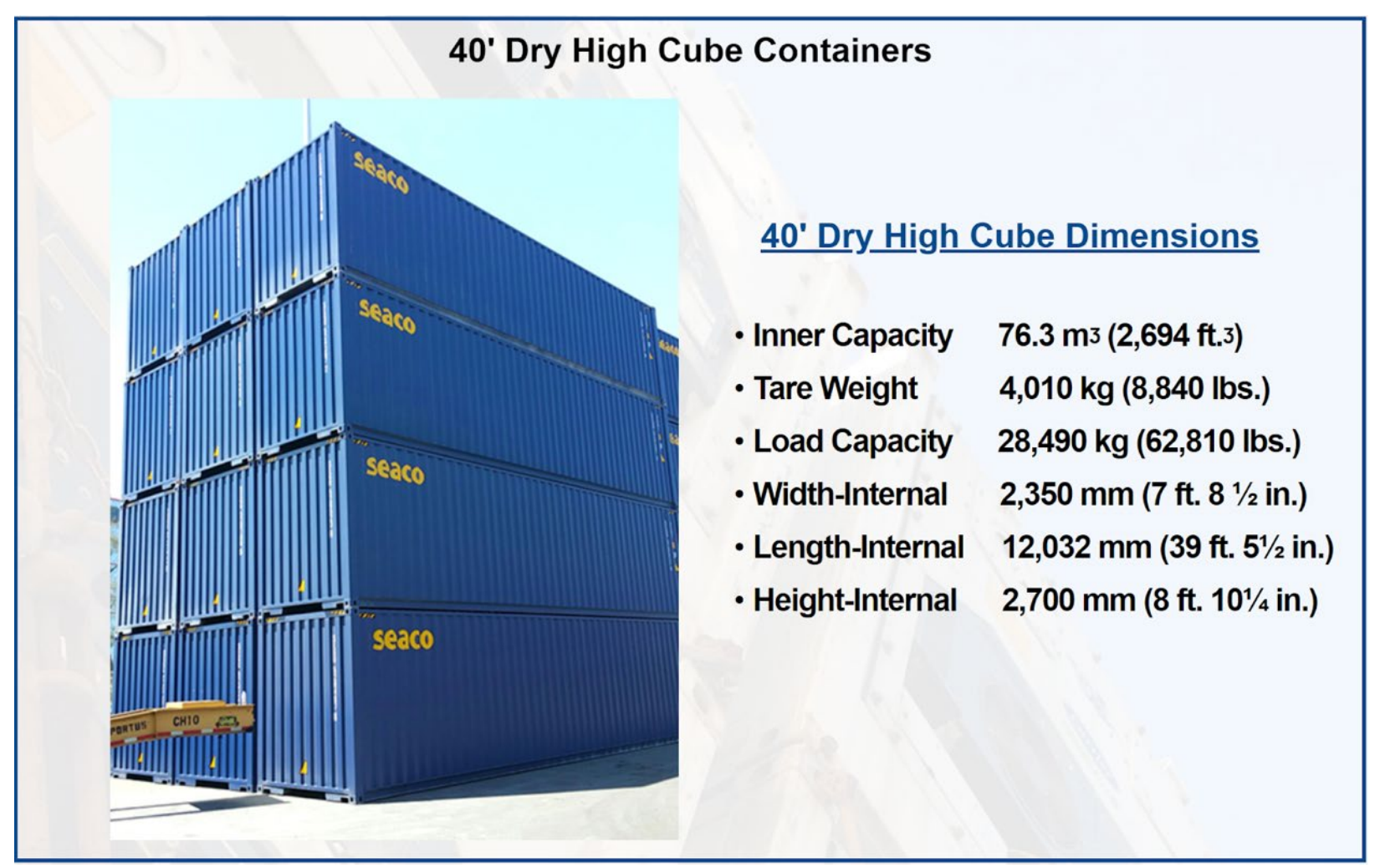

Source: www.worlddirectshipping.com 


\section{Exhibit 2: M. V. Queen B}

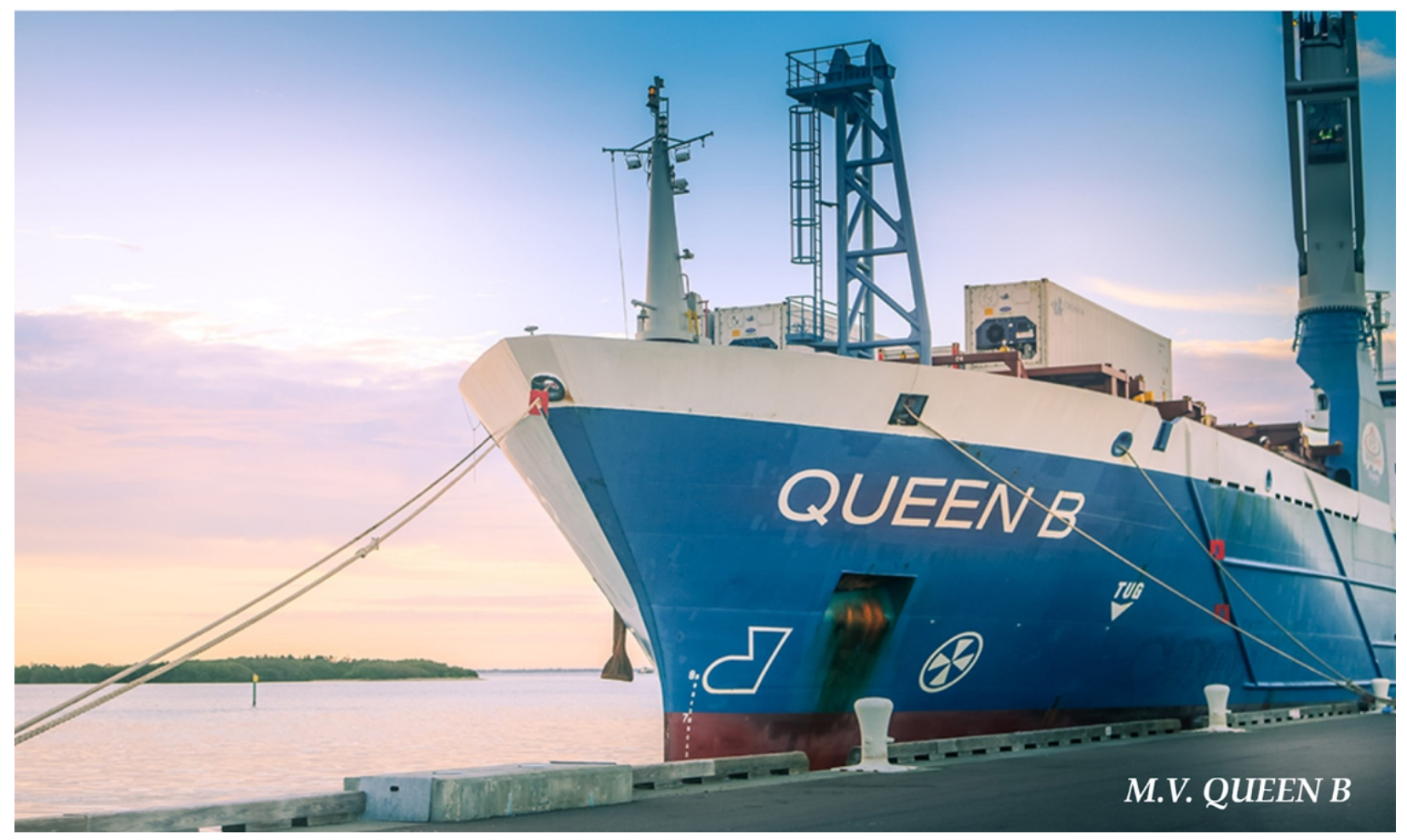

Source: www.worlddirectshipping.com 


\section{Exhibit 3: WDS Operations}

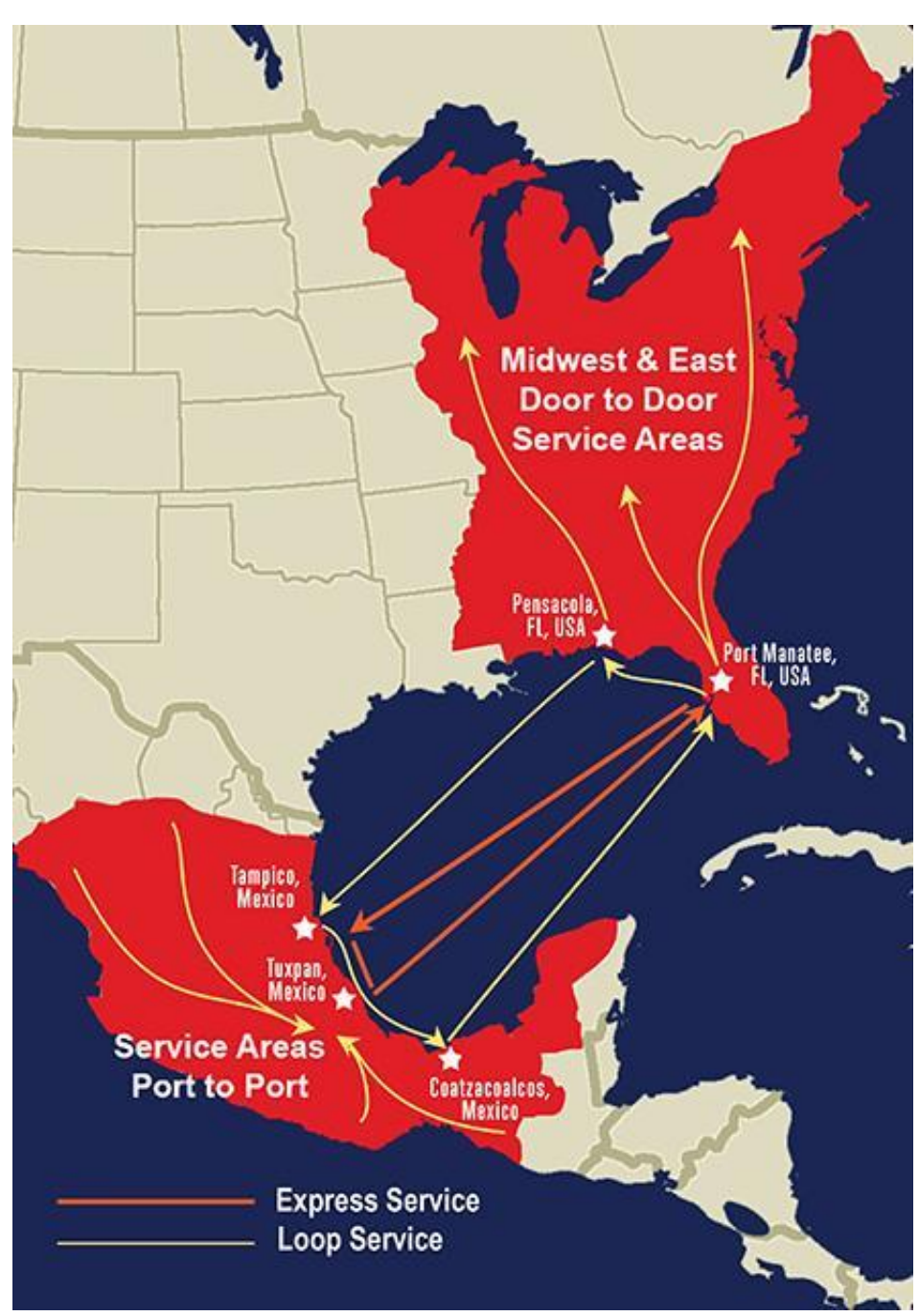

\section{Northbound Service}

LOAD: Tampico, Tamaulipas - Thursday LOAD: Tuxpan, Veracruz - Friday

LOAD: Coatzacoalcos, Veracruz - Sunday

SEA TRANSIT TIME: 21/2 days

DISCHARGE: Port Manatee, FL - Wednesday DISCHARGE: Pensacola, FL - Monday

\section{Southbound Service}

LOAD: Port Manatee, FL - Friday

LOAD: Pensacola, FL - Monday

SEA TRANSIT TIME: $21 / 2$ days

DISCHARGE: Tampico, Tamaulipas - Thursday

DISCHARGE: Tuxpan, Veracruz - Friday

DISCHARGE: Coatzacoalcos, Veracruz - Saturday

Source: www.worlddirectshipping.com 


\section{Exhibit 4: Sample Bill of Lading}

\begin{tabular}{|c|c|c|c|c|c|c|c|}
\hline \multirow{3}{*}{\multicolumn{2}{|c|}{${ }_{* * \star}^{\text {SHIPPER }}$}} & & & \begin{tabular}{|l} 
BOOKING NUMBER \\
72012
\end{tabular} & \multicolumn{3}{|c|}{$\begin{array}{l}\text { BILL OF LADING Number: } \\
\text { WDSB1903014415 }\end{array}$} \\
\hline & & & & CONSOLIDATION NUMBER: & \multicolumn{3}{|c|}{$\begin{array}{l}\text { CONTAINER NUMBER } \\
\text { See Below }\end{array}$} \\
\hline & & & & EXPORT REFERENCES & \multicolumn{3}{|c|}{ SHIPPERS REFERENCE } \\
\hline \multicolumn{4}{|l|}{ CONSIGNEE } & \multicolumn{4}{|l|}{ FORWARDING AGENT } \\
\hline \multirow{2}{*}{\multicolumn{3}{|c|}{ NOTIFY PARTY }} & & \multicolumn{4}{|l|}{$\begin{array}{l}\text { CUSTOMS BROKER } \\
* * *\end{array}$} \\
\hline & & & & \multicolumn{4}{|c|}{$\begin{array}{l}\text { POINT (STATE) OF ORIGIN OR FTZ NUMBER } \\
\text { Tuxpan, Mexico }\end{array}$} \\
\hline \multirow{2}{*}{\multicolumn{3}{|c|}{$\begin{array}{l}\text { Pre-Carriage By: } \\
\text { CLIENTE }\end{array}$}} & $\begin{array}{l}\text { Place of Receipt: } \\
\text { Tuxpan }\end{array}$ & \multirow{2}{*}{\multicolumn{4}{|c|}{ DESTINATION AGENT }} \\
\hline & & & & & & & \\
\hline \multicolumn{3}{|c|}{$\begin{array}{l}\text { Vessel / Voyage: } \\
\text { Queen B / 403N } \\
\end{array}$} & $\begin{array}{l}\text { Port of Loading: } \\
\text { Tuxpan, Mexico }\end{array}$ & \multicolumn{4}{|l|}{$\begin{array}{l}\text { LOADING TERMINAL } \\
\text { VESSEL - OCEAN }\end{array}$} \\
\hline \multicolumn{3}{|c|}{\begin{tabular}{|l} 
Port of Discharge: \\
Port Manatee, United States
\end{tabular}} & $\begin{array}{l}\text { Place of Delivery: } \\
\text { Port Manatte }\end{array}$ & $\begin{array}{l}\text { CO-LOADING WTH } \\
\text { NONE }\end{array}$ & \multicolumn{3}{|c|}{$\begin{array}{l}\text { Containerized: } \\
\text { Yes }\end{array}$} \\
\hline \multicolumn{8}{|c|}{ PARTICULARS FURNISHED BY SHIPPER } \\
\hline \multicolumn{2}{|c|}{ Marks \& Numbers } & $\begin{array}{l}\text { \# of } \\
\text { Pkgs }\end{array}$ & \multicolumn{3}{|c|}{ Description of Goods } & $\begin{array}{c}\text { Gross Weight } \\
(\mathrm{lbs} / \mathrm{kg})\end{array}$ & Type/ISO \\
\hline AGMU6309240 & $267097-267098$ & 1 & \multicolumn{3}{|l|}{ NF Concentrate orange juice } & & 20т0 \\
\hline 1.0 & & & \multicolumn{3}{|l|}{1 Each : NF Concentrate orange juice } & $60000 / 27216$ & \\
\hline AGMU6312428 & $257286-257287$ & 1 & \multicolumn{3}{|l|}{ NF Concentrate orange juice } & & \\
\hline 2.0 & & & \multicolumn{3}{|l|}{1 Each : NF Concentrate orange juice } & $54806 / 24860$ & \\
\hline AGMU6309255 & 0257213-0257214 & 1 & \multicolumn{3}{|l|}{ NF Concentrate orange juice } & & 20т0 \\
\hline 3.0 & & & \multicolumn{3}{|c|}{$\begin{array}{l}1 \text { Each : NF Concentrate orange juice } \\
\text { AESITN: } \\
\text { FREIGHT COLLECT ON BOARD 03/29/2019 AT Tuxpan ON BOARD NAMED VESSEL } \\
\text { Queen B VIA World Direct Shipping. AS CARRIER. }\end{array}$} & $54806 / 24860$ & \\
\hline \multicolumn{6}{|c|}{$\begin{array}{l}\text { The Carries received the above goods in apparent good order and condifion, unless otherwise specified, for carriage to the place as agreed above subject to the terms of this Bill of } \\
\text { Lading including thos e on the back page. }\end{array}$} & \multicolumn{2}{|c|}{ Value declaration as per Article 26} \\
\hline \multirow{4}{*}{\multicolumn{4}{|c|}{ 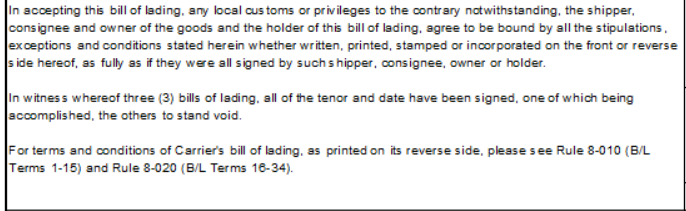 }} & \multicolumn{4}{|c|}{ DESCRIPTION OF GOODS: See Description Above } \\
\hline & & & & \multirow{2}{*}{\multicolumn{3}{|c|}{$\begin{array}{l}\text { B/L RELEASE: WDSBNon-Negotiable } \\
\text { Copy }\end{array}$}} & $\begin{array}{l}\text { Place of } \\
\text { Issuance: }\end{array}$ \\
\hline & & & & & & & \\
\hline & & & & \multicolumn{4}{|l|}{ Total Prepaid } \\
\hline \multicolumn{4}{|c|}{ Date: 03/29/2019 } & \multicolumn{3}{|l|}{ Total Collect } & $\begin{array}{l}\text { Freight Payable } \\
\text { At: }\end{array}$ \\
\hline \multicolumn{4}{|c|}{ Stamp and Signature of the Carrier or its Agent } & $\begin{array}{l}\text { The contract evidenced by this B } \\
\text { States of America. Any proceedir } \\
\text { of the United States of America a }\end{array}$ & $\begin{array}{l}\text { ing is gove } \\
\text { st the Carr } \\
\text { her court. }\end{array}$ & $\begin{array}{l}\text { Ined by the laws } \\
\text { er must be brough }\end{array}$ & $\begin{array}{l}\text { of the United } \\
\text { ght in the courts }\end{array}$ \\
\hline
\end{tabular}

Page 1 of 2

Source: World Direct Shipping 


\section{Exhibit 5: Salesforce Streamline System}

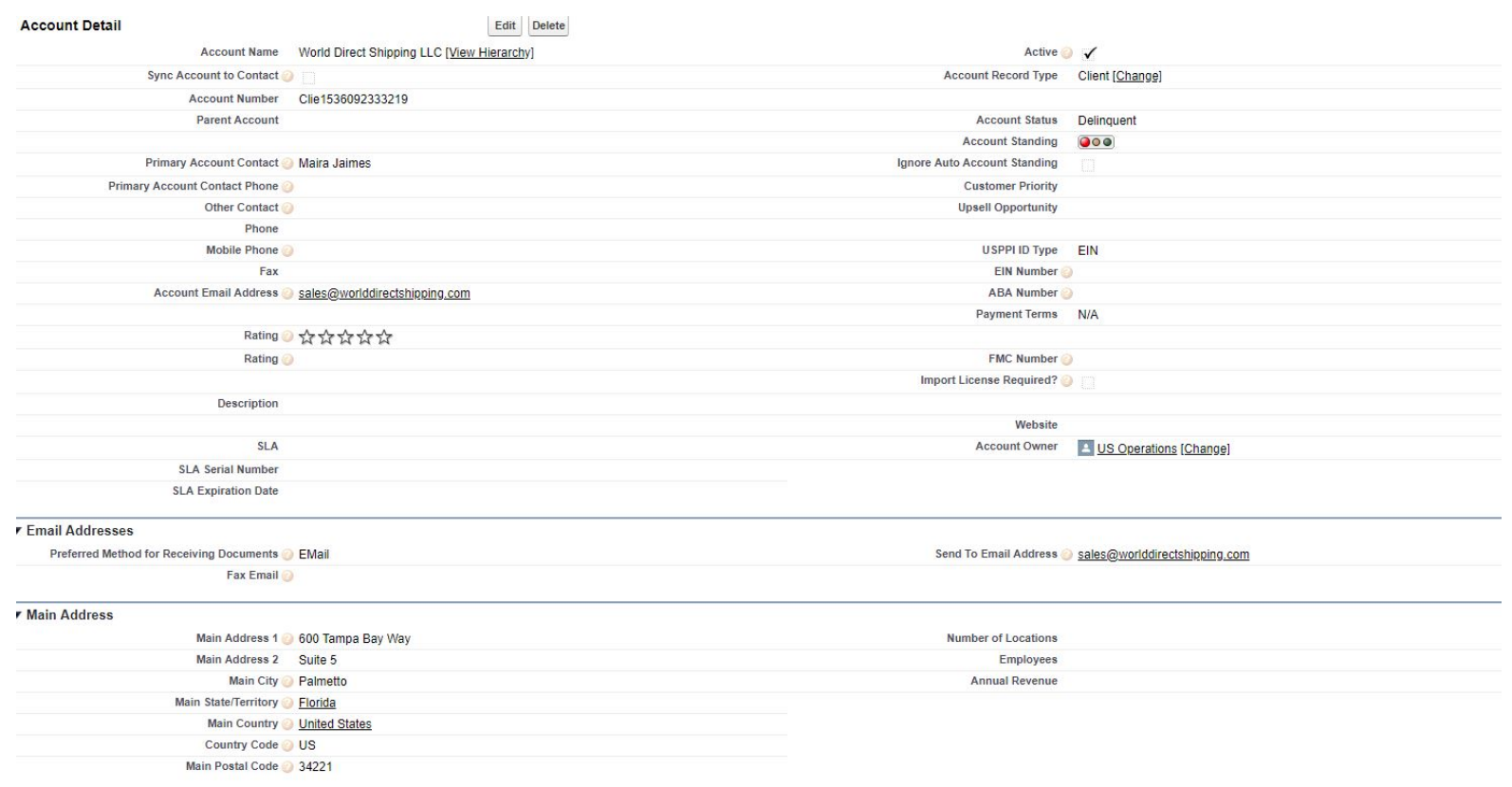

Source: $\underline{\text { www.salesforce.com }}$ 


\section{Exhibit 5.1: Salesforce Streamline Dock Receipt}

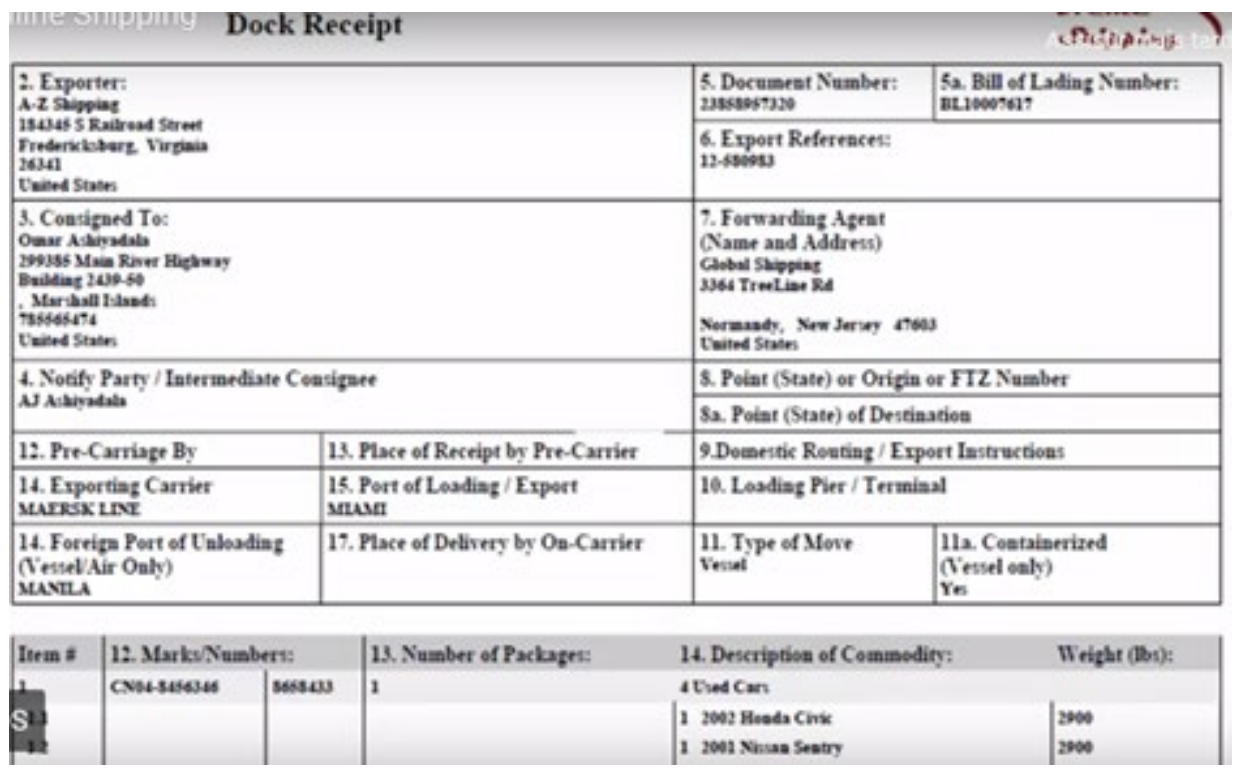

Source: $\underline{w w w . s a l e s f o r c e . c o m ~}$ 


\section{Exhibit 6: Descartes AMS Security Regulations Supported}

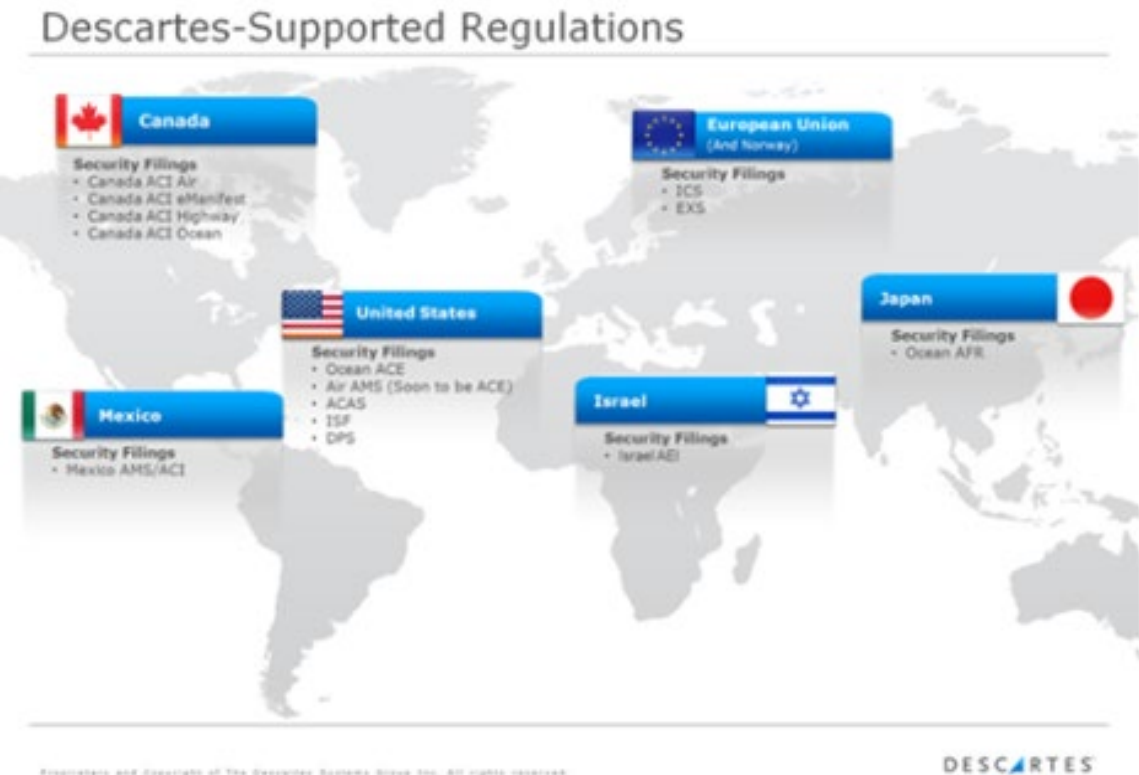

Source: $\underline{w w w . d e s c a r t e s . c o m}$ 


\section{Exhibit 6.1: Descartes AMS Application Status and Depositions}

DE S C $\triangle$ R T E S ocean AMs

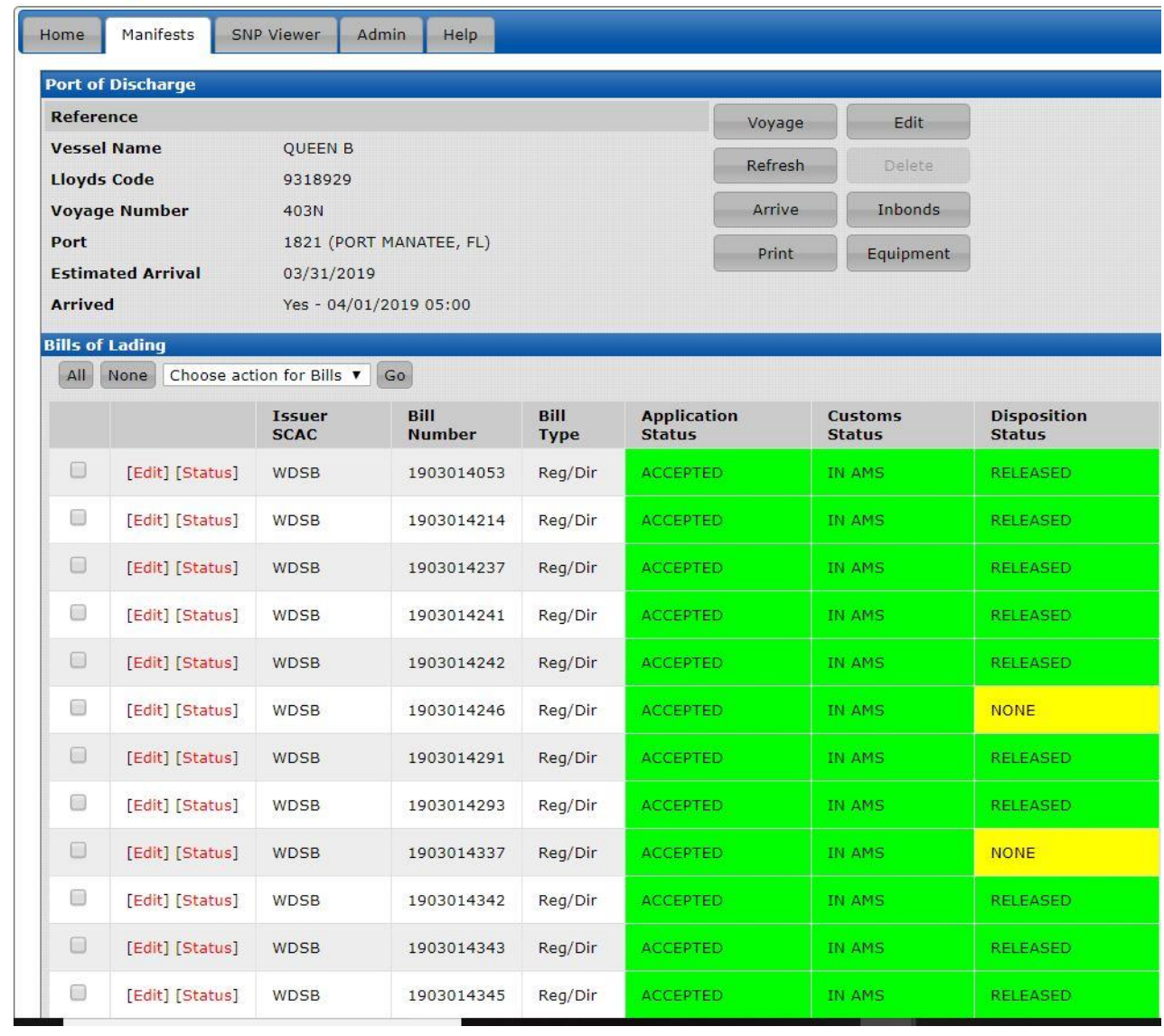

Source: World Direct Shipping 


\section{Exhibit 6.2: Descartes AMS Voyage Status, Ports of Load \& Discharge}

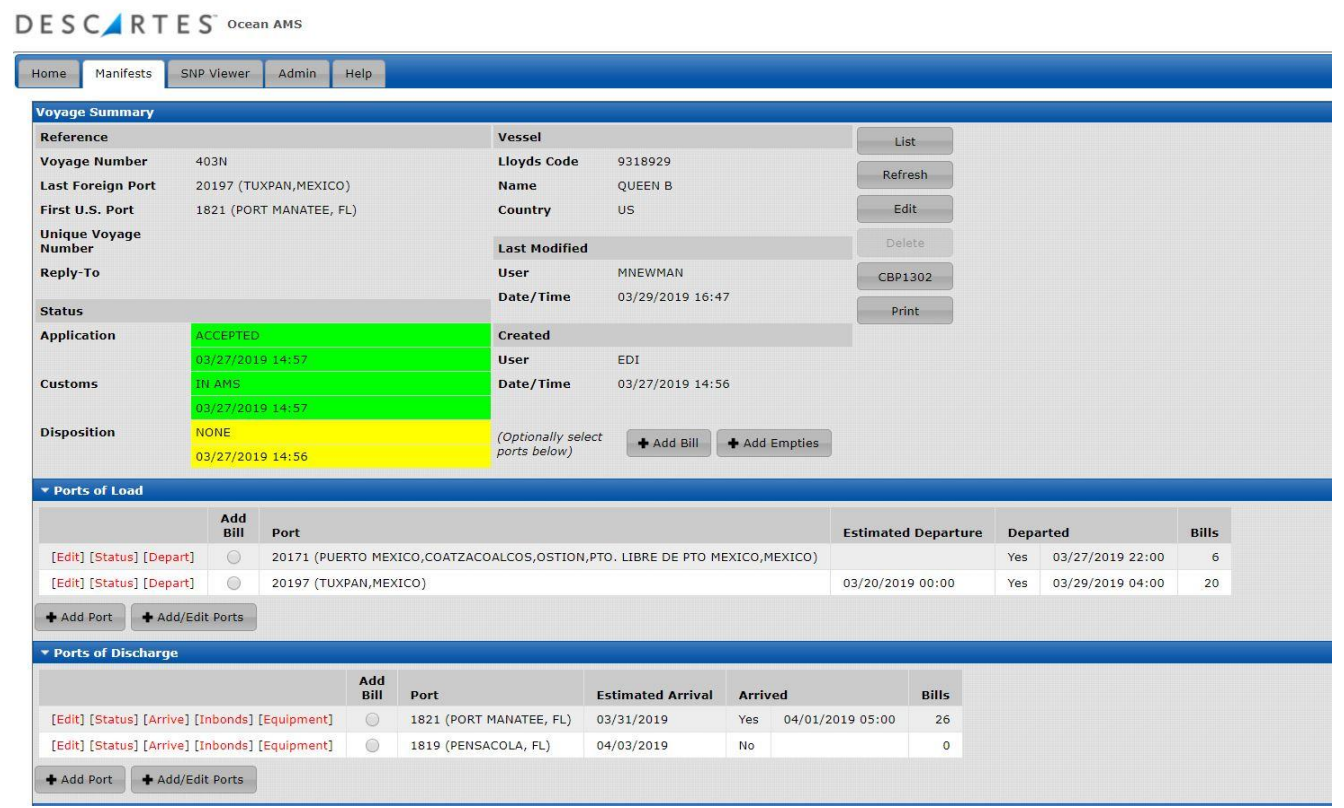

Source: World Direct Shipping 


\section{Exhibit 6.3: Descartes AMS Bill of Lading Input}

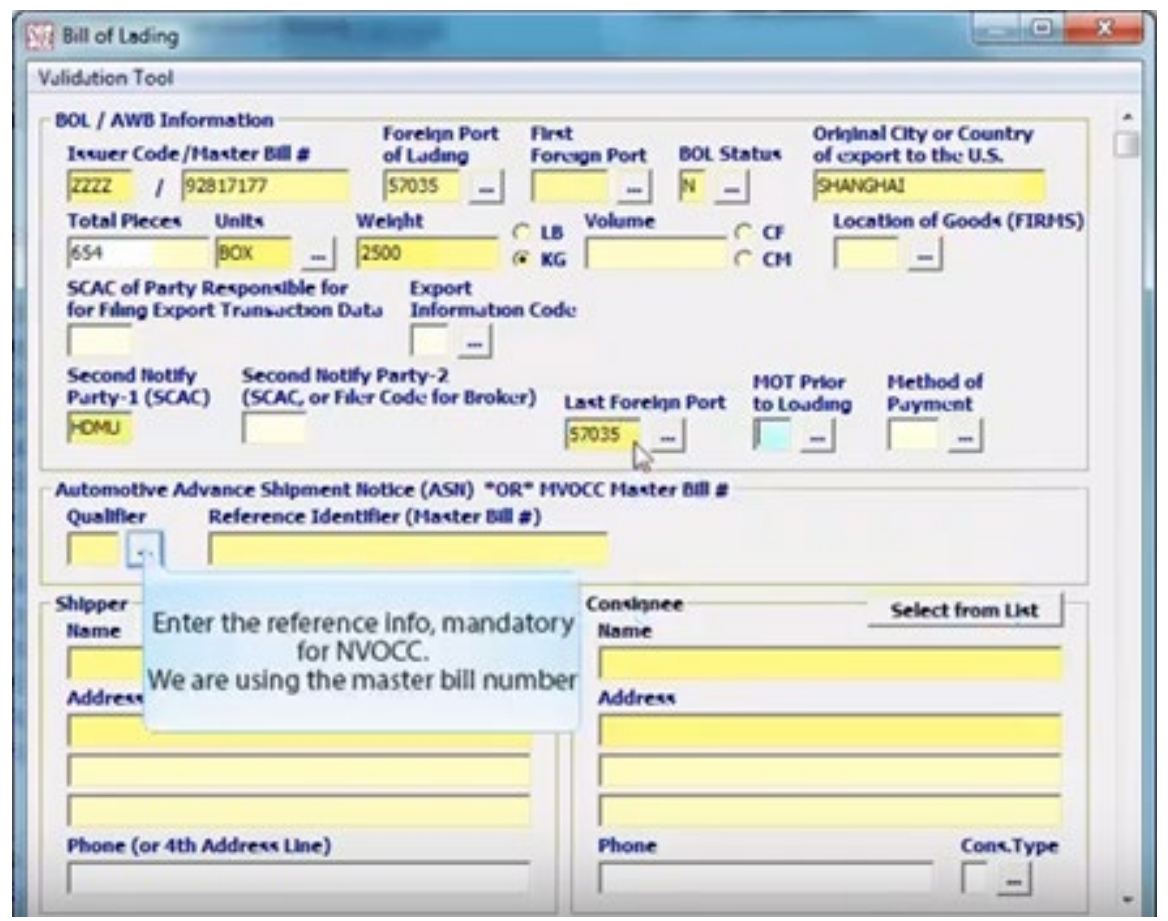

Source: $\underline{w w w . d e s c a r t e s . c o m}$ 
Exhibit 6.4: Descartes AMS Bill of Lading Input

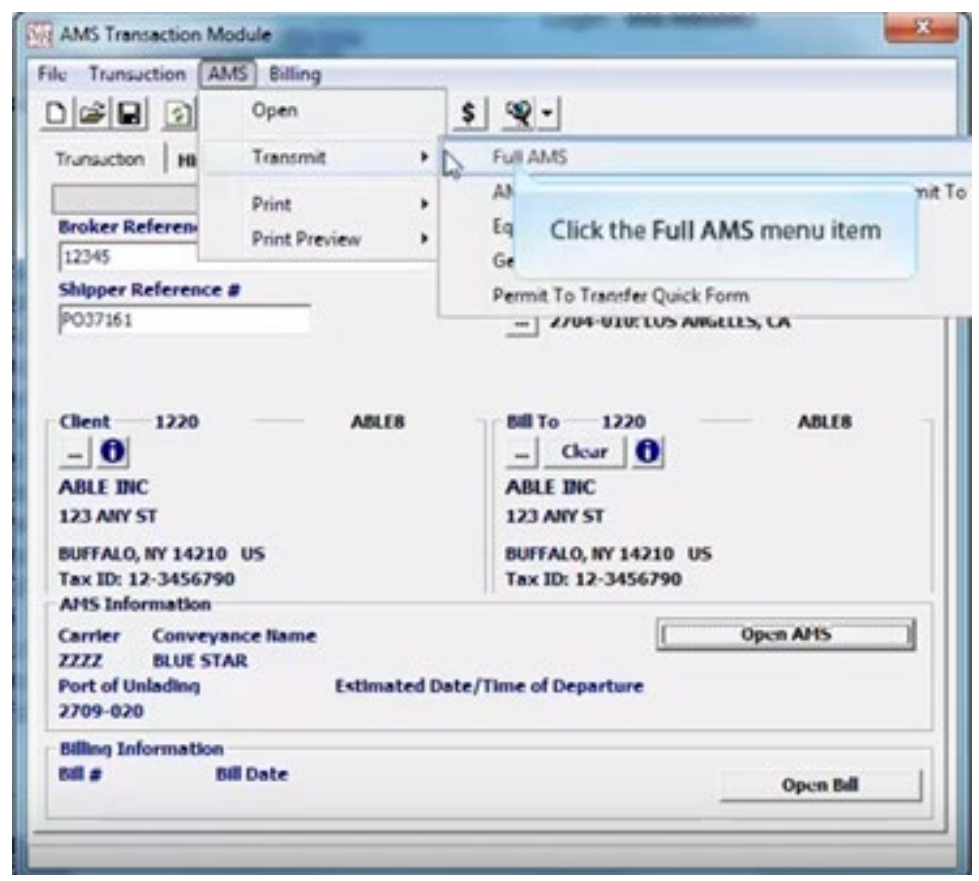

Source: $\underline{\text { www.descartes.com }}$ 


\section{Exhibit 7: Top 8 Logistics Challenges Facing the Industry}

\section{Top Challenges Facing Shippers Today}

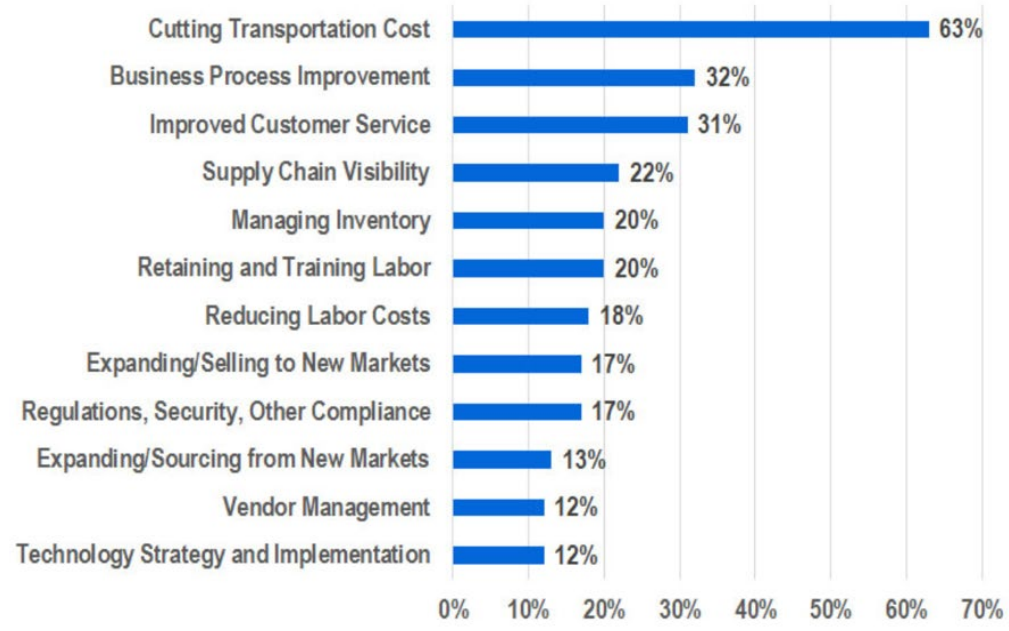

Source: Capgemini Consulting, 2016 State of Third-Party Logistics Study

Source: Capgemini Consulting, 2016 State of Third-Party Logistics Study 


\section{Exhibit 8: Standard Document Exchange vs. EDI}

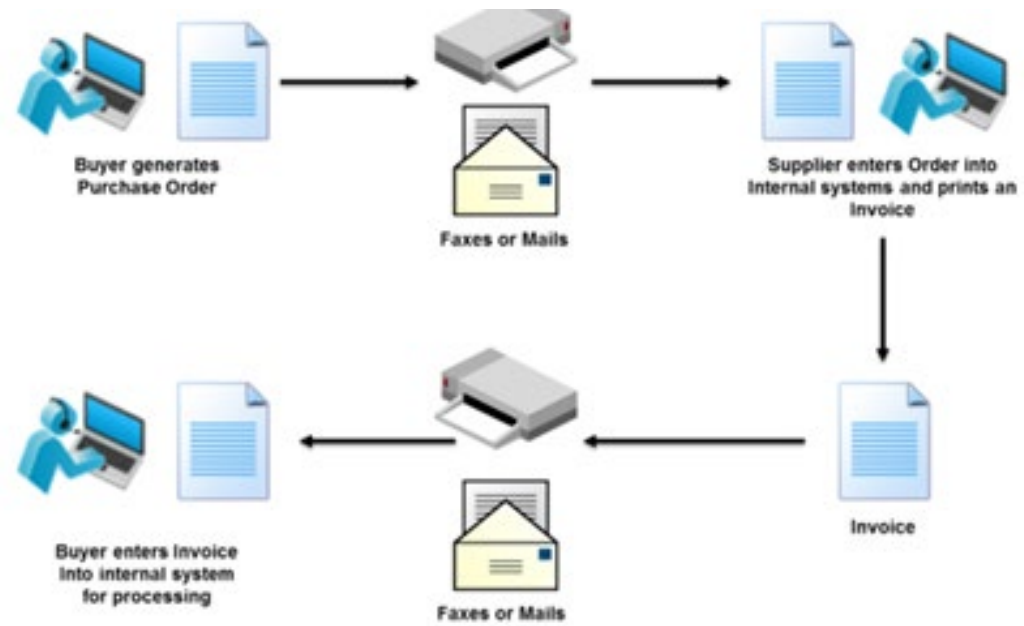

Source: $\underline{w w w . e d i b a s i c s . c o m}$ 


\section{Exhibit 9: RFID Tag}

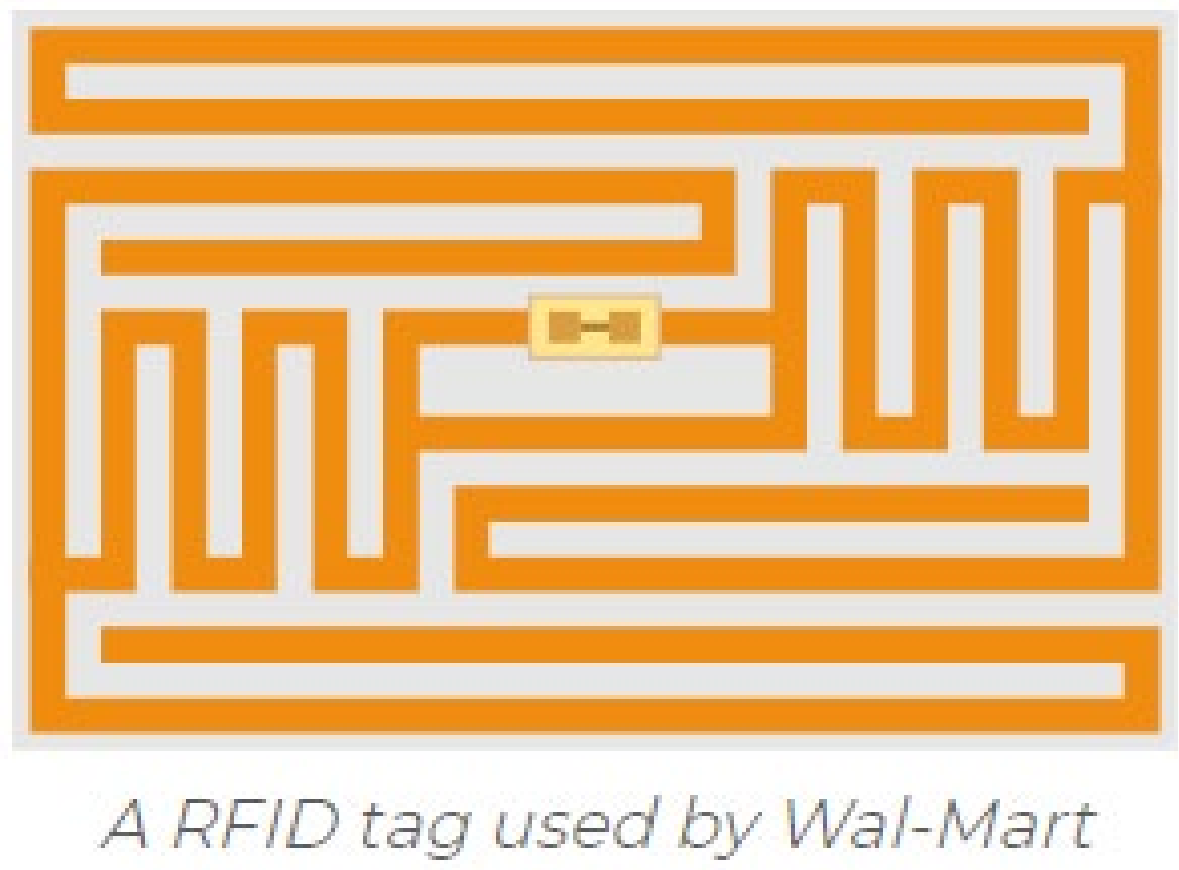

Source: $\underline{\text { www.walmartsupplychain.weebly.com }}$ 